\title{
Academic Motivation and Academic Self-efficacy of Prospective Teachers
}

\author{
Osman Titrek ${ }^{1}$, Ceren Çetin ${ }^{2}$, Esra Kaymak ${ }^{2}$, Merve Melike Kaşikçi ${ }^{2}$ \\ ${ }^{1}$ Prof. Dr. Sakarya University, Education Faculty, Educational Science Dept., Turkey \\ ${ }^{2}$ Master Student, Sakarya University, Institute of Educational Sciences Educational Administration and Supervision, \\ Turkey
}

Correspondence: Ceren Çetin, Master Student, Sakarya University, Institute of Educational Sciences Educational Administration and Supervision, Turkey.

Received: October 10, 2018

doi:10.11114/jets.v6i11a.3803
Accepted: November 1, 2018

Online Published: November 29, 2018

URL: https://doi.org/10.11114/jets.v6i11a.3803

\begin{abstract}
The purpose of this study is to examine the relationships between academic self-efficacy perception of prospective teachers and their academic motivation levels. The study was conducted on 322 prospective teachers (226 female and 96 male) who were in $3^{\text {rd }}$ and $4^{\text {th }}$ grades at Faculty of Education in Sakarya University during Spring term of 2017-2018 academic year. Data was collected through "Academic Motivation Scale" developed by Vallerand et al. (1992) and adapted into Turkish by Karagüven (2012) and "Self-perception of Candidate Teachers on Teaching Proficiency Scale" developed by Çakır, Erkuş, and Kılıç (2004). SPSS 23 package program was used to analyze the data; percentage, frequency, arithmetic mean, standard deviation, independent samples t-test, one-way analysis of variance (ANOVA), Tukey HSD and Pearson Correlation test were used in the data analysis. The results of analyses indicated that academic self-efficacy perception levels of the prospective teachers were at desired level. However, their academic motivation levels were at middle level. The result of the analysis revealed that the prospective teachers who were female and taught at 4th grade had higher academic self-efficacy score whereas significant difference was not found in academic motivation levels in terms of gender and grade. On the other hand, there was a significant difference in both academic self-efficacy perception of the prospective teacher and their academic motivation levels in terms of department variables. Prospective teachers enrolled at the department of Preschool and Science Education had higher academic self-efficacy perception than those enrolled at the department of Computer Education and Instructional Technologies, English, Special Education, Social Science and Mathematics. Prospective teachers enrolled at the department of Psychological Counseling and Guidance and Science Education had higher academic motivation levels than English prospective teachers. Further, significant positive correlations were observed between academic motivation and academic self-efficacy of prospective teachers.
\end{abstract}

Keywords: prospective teacher, academic self-efficacy, academic motivation

\section{Introduction}

Motivation is an inner state that affects occurrence and presentation of behavior, and frequency of it (Sternberg \& Williams, 2009; Slavin, 2006). It can be viewed as a mental power serving people to reach their goals (Sternberg \& Williams, 2009). Motivation is also effective on academic success (Alderman, 2004). Motivating students towards the process of learning would make them eager to learn as well as it would help shape students behavior intended for subject (Slavin, 2006). Highly motivated students are enjoying researching producing learning and enjoying the time spent at school whereas unmotivated students aren't, which makes them unwilling to learn and participate in classes and it effects their effort to learn. They may give up against any challenge they face (Demir Güdül, 2015). This is why it can be said that in order to raise the academic success of students, they should be encouraged to learn. There exist various sources that supports motivation. Encouragement of students can be sorted as recognition for their success, rewarding it or appreciation (Gömleksiz \& Serhatlığlu, 2013). Motivating students is necessary in developing their skills and make them reach their goals. (Ali, Tatlah \& Saeed, 2011, s. 29-32). Therefore, there is a positive correlation between class environment and the ways to success (Hardre', Chen, Huang, Chiang, Jen \& Warden, 2006). Motivation based on a structure that varies from high autonomy to low autonomy because self-determination related to developing psychological functions. (Vallerand, Pelletier, Blais, Briere, Senecal \&Vallieres, 1993, s. 161). According to the theory of self-determination suggested by Deci and Ryan, there are different motivation types that represent self-determination 
degrees. (Guay, Mageau \& Vallerand, 2003, s. 993). Motivation types in self-determination theory are formed by focusing on reasons which accelerates taking action. According to this, motivation types are determined as intrinsic motivation, extrinsic motivation and being unmotivated. Intrinsic motivation implies doing something because it is enjoyable or interesting. However, extrinsic motivation implies doing something for the outcomes. Intrinsic motivation is very important for educators because it causes high quality learning and creativity. On the other hand, the effects of extrinsic motivation should not be ignored because most tasks that educators want students to complete is not interesting or enjoyable. Which is why for an efficient learning it's necessary to use teaching strategies that utilizes extrinsic motivation (Deci-Ryan, 2000, s.55). Extrinsic motivation includes result-oriented activities. Contrary to intrinsic motivation, extrinsic motivation focuses on its benefits instead of enjoying activities. However being unmotivated, is being unable to participate in an activity or not having any of its benefits (Deci-Ryan, 2000, s.60). Many researches revealed the effects of academic motivation on success in school. (Rigby, Deci, Patrick \& Ryan, 1992; Wentzel \&Wigfield, 1998; Henning, 2007; Fortier, Vallerand \& Guay, 1993; Coetzee, 2011). Therefore, it is crucial to make the assessments related to evaluation of motivation in higher education as well as in any grade of education. In this context, doing studies intended especially for prospective teachers has come into prominence. The importance of this study can be understood considering teachers who are evaluated to have high motivation levels are showing higher success in their careers (Gömleksiz \& Serhatlığlu, 2013).

Self-efficacy has become a widespread topic in organizational science fields such as psychology, sociology and education in the last twenty years (Scherbaum, Cohen-Charash \& Kern, 2006). Concept of self-efficacy is first seen in Bandura's social learning theory (1977). Bandura describes self-efficacy as one's organization of the necessary activities and evaluating himself of abilities which needed to accomplish those activities, in order to show a certain performance. Whereas Luszczynska, Scholz and Schwarzer describe self-efficacy as one's faith to their ability to perform necessary deeds in certain situations to reach a goal. According to Yildırım and Ilhan (2010) concept of self-efficacy includes elements such as motivation level that consist of planning an action, being aware of necessary skills and reviewing outcomes that will be obtained. With reference to all this, it can be said that belief of self-efficacy is affecting people's emotions thoughts behaviors and motivation. Self-efficacy indicates a person's power to overcome a problem and how long they can face it. There is trust in human abilities in the foundation of overcoming these problems. Which means people who have faith in their abilities and use it accordingly, can overcome problems they face, whereas people who don't have faith in their abilities can't overcome them and give up. That is why in order for the education to be more effective and efficient; teachers must have a certain level of self-efficacy. (B1kmaz, 2004; Azar, 2010). Self-efficacy level of a teacher is a factor on environment of learning, situation of learning and teaching, and on student's participation to class. Yet it is difficult for a low-level self-efficacy teacher to motivate his/her students, to show them confidence, and to have authority over class. Because of this, teachers' ability to overcome difficult situations has been examined (Demirel, 2012).

Purpose of this research is to determine the correlation between prospective teachers' academic motivation levels and self-efficacy sense. In this context, the following are the sub-problems of this study:

1) What is the self-efficacy perception of prospective teachers?

2) What is the motivation level of prospective teachers?

3) Is there a significant difference between the opinions of prospective teachers regarding the self-efficacy perception of prospective teachers in terms of gender, class, and department?

4) Is there a significant difference between the opinions of prospective teachers regarding the motivation level of prospective teachers in terms of gender, class, and department?

5) What is the correlation between the self-efficacy perception and the motivation level of prospective teachers?

\section{Method}

This section of the study involves the research model, the universe and the sample, the data collection tools, and the data collection and the analysis of data. Correlational model was used. This model aims to describe a past or present situation as it is (Karasar, 2012). The questionnaire was used as data collection technique which is often used in this model (Nachmias \& Nachmias, 1996).

The study population consists of students who were in $3^{\text {rd }}(\mathrm{n}: 827)$ and $4^{\text {th }}(\mathrm{n}: 836)$ grades at Faculty of Education in Sakarya University during Spring term of 2017-2018 academic year. The research sample consisted of 322 prospective teachers (226 female and 96 male) chosen through cluster sampling method. 53,7\% of these prospective teachers are in $3^{\text {rd }}$ grade (n:173), $43,3 \%$ of them (n:149) are in $4^{\text {th }}$ grade. In the cluster sampling method, the population is divided into groups called clusters and each cluster is defined as a unit of sampling. Therefore, sampling is created by combining clusters selected randomly (Çömlekçi, 2001, s.90). Cluster sampling is used when the elements are not listed exactly. 
Especially, it is often difficult to reach the elements that should be sampling in countrywide studies. For example, for a high school research sample, it is difficult to reach the units that come out of the sample even if the list of high school students is found because the sample will be scattered in the community as a result of simple random sampling. In this case, a sample is created by giving a chance to be selected equally to each unit that forms the population instead of working with a common example. Examples selected with cluster sampling are not individual units of the sample universe; they are those clusters that are created by the units (Gökçe, 1988, s. 82). The distribution of the participants according to the departments they study is as follows: Preschool education $11.2 \%$ (n:36), primary school teaching $12.1 \%$ $(\mathrm{n}: 39)$, computer and instructional technologies $11.8 \%(\mathrm{n}: 38)$, English language teaching $9.0 \%$ (n:29), special education $8.7 \%$ (n:28), social sciences teaching $9.3 \%(\mathrm{n}: 30)$, primary education mathematic education $9.3 \%$ (n:30), psychological counseling and guidance $8.1 \%$ (n:26), science teaching $10.9 \%$ (N:35), Turkish teaching 9.6\% (n:31).

To measure the level of academic motivation of prospective teachers, "Academic Motivation Scale" developed by Vallerand et al. (1992) and adapted into Turkish by Karagüven (2012) was used in the study. This 28-item instrument uses a 7-point Likert scale.The scale consists of seven dimensions defined as internal motivation knowing-IMBI, internal motivation achievement-IMBA, internal motivation movement-IMH, external motivation recognition-DMT, external motivation self-proof-DMKI, external motivation regulation-DMD and non-motivation-MS.The rating for the dimensions of the scale is as follows: "strongly disagree, disagree, slightly disagree, undecided, slightly agree, agree and strongly agree". In the development of the scale, the required validity and reliability procedures were applied to 390 senior year students. Cronbach alpha reliability coefficient of the scale was 0.87 .The Cronbach alpha reliability of the sub-dimensions were respectively 0.80 for the IMBIdimension, 0,73 for IMBA dimension, 0,76 for IMH dimension, 0,79 for DMT dimension,0,71 for DMKI dimension, 0.69 for DMD dimension and 0,84 for MS dimension. In the meantime, to measure the academic self-efficacy perceptions of prospective teachers "Self-perception of Candidate Teachers on Teaching Proficiency Scale" developed by Çakır, Erkuş, and Kılıç (2004) was also used in the study. This 30-item instrument uses a 5-point Likert scale which is $1=$ strongly disagree, and 5=strongly agree. Cronbach alpha reliability coefficient of the scale was 0.94 .

SPSS 23 package program was used to analyze the data; Kolmogorov-Smirnov test was applied with the aim of testing whether the data showed normal distribution or not, and parametric tests were carried out, since the data was discovered to distribute normally and percentage, frequency, arithmetic mean, standard deviation, independent samples t-test, one-way analysis of variance (ANOVA) with Schefee and Tukey HSD post-hoc tests (variances for all variables were homogenous) and Pearson Correlation test were used in the data analysis. The results of the analysis were evaluated at the " 0.05 " significance level.

\section{Findings}

In this section, findings will be presented and discussed according to the data analysis.

Table 1. Examination of teacher self-efficacy perception of prospective teacher - the test result of frequency analysis

\begin{tabular}{|c|c|c|c|c|c|c|c|c|c|c|c|c|}
\hline & \multicolumn{2}{|c|}{ Strongly Disagree } & \multicolumn{2}{|c|}{ Disagree } & \multicolumn{2}{|c|}{ Undecided } & \multicolumn{2}{|c|}{ Agree } & \multicolumn{4}{|c|}{ Strongly Agree } \\
\hline & $\mathbf{F}$ & $\%$ & $\mathbf{f}$ & $\%$ & $\mathbf{f}$ & $\%$ & $\mathbf{f}$ & $\%$ & $\mathbf{f}$ & $\%$ & $\overline{\mathbf{x}}$ & SS \\
\hline 1 & 11 & 3,4 & 15 & 4,7 & 53 & 16,5 & 89 & 27,6 & 154 & 47,8 & 4,12 & 1,061 \\
\hline 2 & 3 & 9 & 4 & 1,2 & 47 & 14,6 & 141 & 43,8 & 127 & 39,4 & 4,20 & ,799 \\
\hline 3 & 3 & 9 & 12 & 3,7 & 71 & 22,0 & 138 & 42,9 & 98 & 30,4 & 3,98 & 872 \\
\hline 4 & 3 & 9 & 3 & 9 & 59 & 18,3 & 150 & 46,6 & 107 & 33,2 & 4,10 & ,793 \\
\hline 5 & 3 & 9 & 5 & 1,6 & 82 & 25,5 & 141 & 43,8 & 91 & 28,3 & 3,97 & ,827 \\
\hline 6 & 4 & 1,2 & 3 & 9 & 56 & 17,4 & 154 & 47,8 & 105 & 32,6 & 4,10 & 801 \\
\hline 7 & 1 &, 3 & 5 & 1,6 & 45 & 14,0 & 144 & 44,7 & 127 & 39,4 & 4,21 & ,762 \\
\hline 8 & 3 & 9 & 5 & 1,6 & 47 & 14,6 & 158 & 49,1 & 109 & 33,9 & 4,13 &, 784 \\
\hline 9 & 3 & 9 & 15 & 4,7 & 73 & 22,7 & 145 & 45,0 & 86 & 26,7 & 3,92 & ,872 \\
\hline 10 & 3 & 9 & 10 & 3,1 & 80 & 24,8 & 144 & 44,7 & 85 & 26,4 & 3,93 & ,847 \\
\hline 11 & 2 & 6 & 15 & 4,7 & 69 & 21,4 & 136 & 42,2 & 100 & 31,1 & 3,98 & 877 \\
\hline 12 & 2 & 6 & 10 & 3,1 & 52 & 16,1 & 147 & 45,7 & 111 & 34,5 & 4,10 & 823 \\
\hline 13 & 1 & ,3 & 8 & 2,5 & 83 & 25,8 & 145 & 45,0 & 85 & 26,4 & 3,95 & 805 \\
\hline 14 & 4 & 1,2 & 11 & 3,4 & 50 & 15,5 & 149 & 46,3 & 108 & 33,5 & 4,07 & 858 \\
\hline 15 & 6 & 1,9 & 9 & 2,8 & 64 & 19,9 & 132 & 41,0 & 111 & 34,5 & 4,03 & 908 \\
\hline 16 & 2 & 6 & 12 & 3,7 & 68 & 21,1 & 115 & 35,7 & 125 & 38,8 & 4,08 & 894 \\
\hline 17 & 5 & 1,6 & 21 & 6,5 & 85 & 26,4 & 131 & 40,7 & 80 & 24,8 & 3,81 & ,937 \\
\hline 18 & 3 &, 9 & 5 & 1,6 & 47 & 14,6 & 113 & 35,1 & 154 & 47,8 & 4,27 & ,835 \\
\hline 19 & 4 & 1,2 & 6 & 1,9 & 51 & 15,8 & 154 & 47,8 & 107 & 33,2 & 4,10 & 818 \\
\hline 20 & 8 & 2,5 & 16 & 5,0 & 74 & 23,0 & 120 & 37,3 & 104 & 32,3 & 3,92 & ,986 \\
\hline 21 & 3 & ,9 & 8 & 2,5 & 51 & 15,8 & 141 & 43,8 & 119 & 37,0 & 4,13 & 834 \\
\hline
\end{tabular}




\begin{tabular}{|c|c|c|c|c|c|c|c|c|c|c|c|c|}
\hline 22 & 2 & ,6 & 4 & 1,2 & 28 & 8,7 & 133 & 41,3 & 15 & 48,1 & 4,35 &, 743 \\
\hline 23 & 5 & 1,6 & 5 & 1,6 & 38 & 11,8 & 122 & 37,9 & 152 & 47,2 & 4,28 & ,847 \\
\hline 24 & 3 & ,9 & 7 & 2,2 & 43 & 13,4 & 118 & 36,6 & 151 & 46,9 & 4,26 & ,840 \\
\hline 25 & 3 & ,9 & 2 & ,6 & 35 & 10,9 & 125 & 38,8 & 157 & 48,8 & 4,34 &, 770 \\
\hline 26 & 2 & 6 & 10 & 3,1 & 39 & 12,1 & 129 & 40,1 & 142 & 44,1 & 4,24 & ,829 \\
\hline 27 & 2 & ,6 & 9 & 2,8 & 51 & 15,8 & 101 & 31,4 & 159 & 49,4 & 4,26 & ,868 \\
\hline 28 & 4 & 1,2 & 9 & 2,8 & 61 & 18,9 & 121 & 37,6 & 127 & 39,4 & 4,11 & ,893 \\
\hline 29 & 3 & ,9 & 10 & 3,1 & 63 & 19,6 & 137 & 42,5 & 109 & 33,9 & 4,05 &, 861 \\
\hline 30 & 7 & 2,2 & 17 & 5,3 & 75 & 23,3 & 108 & 33,5 & 115 & 35,7 & 3,95 & ,999 \\
\hline Average & & & & & & & & & & & 4,09 &, 526 \\
\hline
\end{tabular}

In the context of self-efficacy, the average of the prospective teachers' perception levels was found 4,09 which means "agree". This finding indicates that the level of self-efficacy perception of prospective teachers is sufficient. The standard deviation of ,526 could be considered as an indicator of the parallelism and consistency between prospective teachers' views.

Table 2. Examination of the level of academic motivation of prospective teachers regarding the DMD dimension - the test result of frequency analysis

\begin{tabular}{|c|c|c|c|c|c|c|c|c|c|c|c|c|c|c|c|c|}
\hline & \multicolumn{2}{|c|}{$\begin{array}{l}\text { Strongly } \\
\text { Disagree }\end{array}$} & \multicolumn{2}{|c|}{ Disagree } & \multicolumn{2}{|c|}{$\begin{array}{l}\text { Slightly } \\
\text { Disagree }\end{array}$} & \multicolumn{2}{|c|}{ Undecided } & \multicolumn{2}{|c|}{$\begin{array}{l}\text { Slightly } \\
\text { Agree }\end{array}$} & \multicolumn{2}{|c|}{ Agree } & \multicolumn{4}{|c|}{$\begin{array}{l}\text { Strongly } \\
\text { Agree }\end{array}$} \\
\hline & f & $\%$ & $\mathbf{F}$ & $\%$ & $\mathbf{f}$ & $\%$ & $\mathbf{f}$ & $\%$ & $\mathbf{f}$ & $\%$ & $\mathbf{f}$ & $\%$ & $\mathbf{f}$ & $\%$ & $\overline{\mathbf{x}}$ & SS \\
\hline 1 & 60 & 18,6 & 29 & 9,0 & 26 & 8,1 & 47 & 14,6 & 45 & 14,0 & 32 & 9,9 & 83 & 25,8 & 4,29 & 2,215 \\
\hline 8 & 13 & 4,0 & 11 & 3,4 & 20 & 2,6 & 48 & 14,9 & 55 & 17,1 & 78 & 24,2 & 97 & 30,1 & 5,31 & 1,647 \\
\hline 15 & 2 & 6 & 7 & 2,2 & 9 & 2,8 & 33 & 10,2 & 45 & 14,0 & 88 & 27,3 & 138 & 42,9 & 5,88 & 1,313 \\
\hline 22 & 26 & 8,1 & 12 & 3,7 & 33 & 10,2 & 51 & 15,8 & 65 & 20,2 & 68 & 21,1 & 67 & 20,8 & 4,83 & 1,794 \\
\hline Average & & & & & & & & & & & & & & & 5,07 & 1,281 \\
\hline
\end{tabular}

The arithmetic mean of DMD dimension is 5,07 which means "slightly agree". This finding proves that the level of academic motivation for the DMD dimension is sufficient for prospective teachers. On the other hand, the standard deviation of this dimension is 1,281. This finding indicates that the consensus among prospective teachers is moderate and they stated similar opinions.

Table 3. Examination of the level of academic motivation of prospective teachers regarding the IMBI dimension - the test result of frequency analysis

\begin{tabular}{|c|c|c|c|c|c|c|c|c|c|c|c|c|c|c|c|c|}
\hline & \multicolumn{4}{|c|}{ Strongly } & \multicolumn{2}{|c|}{ Slightly } & \multicolumn{2}{|c|}{ Undecided } & \multicolumn{2}{|c|}{$\begin{array}{l}\text { Slightly } \\
\text { Agree }\end{array}$} & \multicolumn{2}{|c|}{ Agree } & \multicolumn{4}{|c|}{$\begin{array}{l}\text { Strongly } \\
\text { Agree }\end{array}$} \\
\hline & f & $\%$ & f & $\%$ & f & $\%$ & f & $\%$ & f & $\%$ & f & $\%$ & f & $\%$ & $\overline{\mathbf{x}}$ & SS \\
\hline 2 & 8 & 2,5 & 7 & 2,2 & 1 & 4,3 & 41 & 12,7 & 57 & 17,7 & 100 & 31,1 & 95 & 29,5 & 5,52 & 1,456 \\
\hline 9 & 11 & 3,4 & 14 & 4,3 & 22 & 6,8 & 41 & 12,7 & 75 & 23,3 & 94 & 29,2 & 65 & 20,2 & 5,16 & 1,555 \\
\hline 16 & 5 & 1,6 & 10 & 3,1 & 18 & 5,6 & 43 & 13,4 & 69 & 21,4 & 84 & 26,1 & 93 & 28,9 & 5,44 & 1,455 \\
\hline 23 & 13 & 4,0 & 9 & 2,8 & 29 & 9,0 & 41 & 12,7 & 78 & 24,2 & 83 & 25,8 & 69 & 21,4 & 5,13 & 1,578 \\
\hline Average & & & & & & & & & & & & & & & 5,31 & 1,194 \\
\hline
\end{tabular}

The arithmetic mean of IMBI dimension is 5,31 which means "slightly agree". This finding proves that the level of academic motivation for the IMBI dimension is sufficient for prospective teachers. On the other hand, the standard deviation of this dimension is 1,194 . This finding indicates that the consensus among prospective teachers is moderate and they stated similar opinions.

Table 4. Examination of the level of academic motivation of prospective teachers regarding the DMT dimension - the test result of frequency analysis

\begin{tabular}{|c|c|c|c|c|c|c|c|c|c|c|c|c|c|c|c|c|}
\hline & \multicolumn{2}{|c|}{$\begin{array}{l}\text { Strongly } \\
\text { Disagree }\end{array}$} & \multicolumn{2}{|c|}{ Disagree } & \multicolumn{2}{|c|}{$\begin{array}{l}\text { Slightly } \\
\text { Disagree }\end{array}$} & \multicolumn{2}{|c|}{ Undecided } & \multicolumn{2}{|c|}{$\begin{array}{l}\text { Slightly } \\
\text { Agree }\end{array}$} & \multicolumn{2}{|c|}{ Agree } & \multicolumn{2}{|c|}{$\begin{array}{l}\text { Strongly } \\
\text { Agree }\end{array}$} & \multirow[b]{2}{*}{$\overline{\mathbf{x}}$} & \multirow[b]{2}{*}{ SS } \\
\hline & f & $\%$ & f & $\%$ & f & $\%$ & f & $\%$ & f & $\%$ & f & $\%$ & f & $\%$ & & \\
\hline 3 & 5 & 1,6 & 12 & 3,7 & 16 & 5,0 & 35 & 10,9 & 53 & 16,5 & 91 & 28,3 & 110 & 34,2 & 5,58 & 1,485 \\
\hline 10 & 10 & 3,1 & 11 & 3,4 & 25 & 7,8 & 49 & 15,2 & 56 & 17,4 & 86 & 26,7 & 85 & 26,4 & 5,26 & 1,591 \\
\hline 17 & 6 & 1,9 & 8 & 2,5 & 16 & 5,0 & 50 & 15,5 & 65 & 20,2 & 86 & 26,7 & 91 & 28,3 & 5,43 & 1,448 \\
\hline 24 & 7 & 2,2 & 9 & 2,8 & 13 & 4,0 & 59 & 18,3 & 61 & 18,9 & 80 & 24,8 & 93 & 28,9 & 5,39 & 1,484 \\
\hline Average & & & & & & & & & & & & & & & 5,41 & 1,182 \\
\hline
\end{tabular}

The arithmetic mean of DMT dimension is 5,41 which means "slightly agree". This finding proves that the level of academic motivation for the DMT dimension is sufficient for prospective teachers. On the other hand, the standard deviation of this dimension is 1,182 . This finding indicates that the consensus among prospective teachers is moderate 
and they stated similar opinions.

Table 5. Examination of the level of academic motivation of prospective teachers regarding the IMH dimension - the test result of frequency analysis

\begin{tabular}{|c|c|c|c|c|c|c|c|c|c|c|c|c|c|c|c|c|}
\hline & \multicolumn{2}{|c|}{$\begin{array}{l}\text { Strongly } \\
\text { Disagree }\end{array}$} & \multicolumn{2}{|c|}{ Disagree } & \multicolumn{2}{|c|}{$\begin{array}{l}\text { Slightly } \\
\text { Disagree }\end{array}$} & \multicolumn{2}{|c|}{ Undecided } & \multicolumn{2}{|c|}{$\begin{array}{l}\text { Slightly } \\
\text { Agree }\end{array}$} & \multicolumn{2}{|c|}{ Agree } & \multicolumn{4}{|c|}{$\begin{array}{l}\text { Strongly } \\
\text { Agree }\end{array}$} \\
\hline & $\mathbf{F}$ & $\%$ & f & $\%$ & f & $\%$ & f & $\%$ & f & $\%$ & f & $\%$ & f & $\%$ & $\overline{\mathbf{x}}$ & SS \\
\hline 4 & 9 & 2,8 & 14 & 4,3 & 35 & 10,9 & 76 & 23,6 & 71 & 22,0 & 81 & 25,2 & 36 & 11,2 & 4,78 & 1,472 \\
\hline 11 & 21 & 6,5 & 26 & 8,1 & 49 & 15,2 & 65 & 20,2 & 66 & 20,5 & 50 & 15,5 & 45 & 14,0 & 4,43 & 1,725 \\
\hline 18 & 25 & 7,8 & 24 & 7,5 & 44 & 13,7 & 73 & 22,7 & 62 & 19,3 & 60 & 18,6 & 34 & 10,6 & 4,36 & 1,703 \\
\hline 25 & 18 & 5,6 & 16 & 5,0 & 28 & 8,7 & 54 & 16,8 & 82 & 25,5 & 84 & 26,1 & 40 & 12,4 & 4,80 & 1,607 \\
\hline Average & & & & & & & & & & & & & & & 4,59 & 1,242 \\
\hline
\end{tabular}

The arithmetic mean of IMH dimension is 4,59 which means "slightly agree". This finding proves that the level of academic motivation for the IMH dimension is sufficient for prospective teachers. On the other hand, the standard deviation of this dimension is 1,182 . This finding indicates that the consensus among prospective teachers is moderate and they stated similar opinions.

Table 6. Examination of the level of academic motivation of prospective teachers regarding the MS dimension - the test result of frequency analysis

\begin{tabular}{|c|c|c|c|c|c|c|c|c|c|c|c|c|c|c|c|c|}
\hline & \multicolumn{2}{|c|}{$\begin{array}{l}\text { Strongly } \\
\text { Disagree }\end{array}$} & \multicolumn{2}{|c|}{ Disagree } & \multicolumn{2}{|c|}{$\begin{array}{l}\text { Slightly } \\
\text { Disagree }\end{array}$} & \multicolumn{2}{|c|}{ Undecided } & \multicolumn{2}{|c|}{$\begin{array}{l}\text { Slightly } \\
\text { Agree }\end{array}$} & \multicolumn{2}{|c|}{ Agree } & \multicolumn{2}{|c|}{$\begin{array}{l}\text { Strongly } \\
\text { Agree }\end{array}$} & \multirow[b]{2}{*}{$\overline{\mathbf{x}}$} & \multirow[b]{2}{*}{ SS } \\
\hline & $\mathbf{f}$ & $\%$ & $\mathbf{f}$ & $\%$ & f & $\%$ & f & $\%$ & $\mathbf{f}$ & $\%$ & $\mathbf{f}$ & $\%$ & f & $\%$ & & \\
\hline 5 & 96 & 29,8 & 59 & 18,3 & 33 & 10,2 & 42 & 13,0 & 37 & 11,5 & 29 & 9,0 & 26 & 8,1 & 3,17 & 2,013 \\
\hline 12 & 146 & 45,3 & 51 & 15,8 & 23 & 7,1 & 33 & 10,2 & 23 & 7,1 & 27 & 8,4 & 19 & 5,9 & 2,67 & 1,990 \\
\hline 19 & 168 & 52,2 & 44 & 13,7 & 18 & 5,6 & 35 & 10,9 & 25 & 7,8 & 19 & 5,9 & 13 & 4,0 & 2,42 & 1,870 \\
\hline 26 & 151 & 46,9 & 49 & 15,2 & 30 & 9,3 & 29 & 9,0 & 28 & 8,7 & 17 & 5,3 & 18 & 5,6 & 2,56 & 1,910 \\
\hline Average & & & & & & & & & & & & & & & 2,70 & 1,614 \\
\hline
\end{tabular}

The arithmetic mean of MS dimension is 2,70 which means "disagree". This finding proves that the level of academic motivation for the IMH dimension is insufficient for prospective teachers. On the other hand, the standard deviation of this dimension is 1,614 . This finding indicates that the consensus among prospective teachers is moderate and they stated similar opinions.

Table 7. Examination of the level of academic motivation of prospective teachers regarding the IMBA dimension - the test result of frequency analysis

\begin{tabular}{|c|c|c|c|c|c|c|c|c|c|c|c|c|c|c|c|c|}
\hline & \multicolumn{2}{|c|}{$\begin{array}{l}\text { Strongly } \\
\text { Disagree }\end{array}$} & \multicolumn{2}{|c|}{ Disagree } & \multicolumn{2}{|c|}{$\begin{array}{l}\text { Slightly } \\
\text { Disagree }\end{array}$} & \multicolumn{2}{|c|}{ Undecided } & \multicolumn{2}{|c|}{$\begin{array}{l}\text { Slightly } \\
\text { Agree }\end{array}$} & \multicolumn{2}{|c|}{ Agree } & \multicolumn{2}{|c|}{$\begin{array}{l}\text { Strongly } \\
\text { Agree }\end{array}$} & \multirow[b]{2}{*}{$\overline{\mathbf{x}}$} & \multirow[b]{2}{*}{ SS } \\
\hline & $\mathbf{f}$ & $\%$ & f & $\%$ & f & $\%$ & f & $\%$ & $\mathbf{f}$ & $\%$ & $\mathbf{f}$ & $\%$ & f & $\%$ & & \\
\hline 6 & 26 & 8,1 & 16 & 5,0 & 46 & 14 & 66 & 20,5 & 63 & 19,6 & 61 & 18,9 & 44 & 13,7 & 4,50 & 1,735 \\
\hline 13 & 9 & 2,8 & 20 & 6,2 & 28 & 8,7 & 50 & 15,5 & 70 & 21,7 & 86 & 26,7 & 59 & 18,3 & 5,01 & 1,587 \\
\hline 20 & 67 & 20,8 & 40 & 12,4 & 55 & 17,1 & 57 & 17,7 & 54 & 16,8 & 30 & 9,3 & 19 & 5,9 & 3,49 & 1,833 \\
\hline 27 & 28 & 8,7 & 29 & 9,0 & 42 & 13,0 & 56 & 17,4 & 67 & 20,8 & 62 & 19,3 & 38 & 11,8 & 4,38 & 1,784 \\
\hline Average & & & & & & & & & & & & & & & 4,34 & 1,296 \\
\hline
\end{tabular}

The arithmetic mean of IMBA dimension is 4,34 which means "undecided". This finding proves that the level of academic motivation for the IMBA dimension is moderate for prospective teachers. On the other hand, the standard deviation of this dimension is 1,296 . This finding indicates that the consensus among prospective teachers is moderate and they stated similar opinions. 
Table 8. Examination of the level of academic motivation of prospective teachers regarding the DMKI dimension - the test result of frequency analysis

\begin{tabular}{|c|c|c|c|c|c|c|c|c|c|c|c|c|c|c|c|c|}
\hline & \multicolumn{2}{|c|}{$\begin{array}{l}\text { Strongly } \\
\text { Disagree }\end{array}$} & \multicolumn{2}{|c|}{ Disagree } & \multicolumn{2}{|c|}{$\begin{array}{l}\text { Slightly } \\
\text { Disagree }\end{array}$} & \multicolumn{2}{|c|}{ Undecided } & \multicolumn{2}{|c|}{$\begin{array}{l}\text { Slightly } \\
\text { Agree }\end{array}$} & \multicolumn{2}{|c|}{ Agree } & \multicolumn{4}{|c|}{$\begin{array}{l}\text { Strongly } \\
\text { Agree }\end{array}$} \\
\hline & f & $\%$ & f & $\%$ & f & $\%$ & f & $\%$ & f & $\%$ & $\mathbf{f}$ & $\%$ & f & $\%$ & $\overline{\overline{\mathbf{x}}}$ & SS \\
\hline 7 & 56 & 17,4 & 42 & 13,0 & 47 & 14,6 & 50 & 15,5 & 53 & 16,5 & 44 & 13,7 & 30 & 9,3 & 3,79 & 1,936 \\
\hline 14 & 11 & 3,4 & 8 & 2,5 & 24 & 7,5 & 34 & 10,6 & 67 & 20,8 & 95 & 29,5 & 83 & 25,8 & 5,34 & 1,546 \\
\hline 21 & 87 & 27,0 & 44 & 13,7 & 50 & 15,5 & 51 & 15,8 & 38 & 11,8 & 30 & 9,3 & 22 & 6,8 & 3,27 & 1,928 \\
\hline & 33 & 10,2 & 30 & 9,3 & 34 & 10,6 & 52 & 16,1 & 58 & 18,0 & 57 & 17,7 & 58 & 18,0 & 4,48 & 1,922 \\
\hline Average & & & & & & & & & & & & & & & 4,21 & 1,354 \\
\hline
\end{tabular}

The arithmetic mean of DMKI dimension is 4,21 which means "undecided". This finding proves that the level of academic motivation for the DMKI dimension is moderate for prospective teachers. On the other hand, the standard deviation of this dimension is 1,354 . This finding indicates that the consensus among prospective teachers is moderate and they stated similar opinions.

Table 9. Academic self-efficacy perceptions t-test results by gender

\begin{tabular}{lllllcc}
\hline Gender & $\mathbf{N}$ & $\overline{\mathbf{x}}$ & $\mathbf{S s}$ & $\mathbf{s d}$ & $\mathbf{t}$ & $\mathbf{p}$ \\
\hline Female & 226 & 4,17 & 0,483 & 320 & 4,33 & 0,000 \\
Male & 96 & 3,90 & 0,574 & & & \\
\hline
\end{tabular}

When the Table 9 is examined, it is seen that there is a significant difference between the gender of prospective teachers and their academic self-efficacy $(\mathrm{p}<0,05)$. The female prospective teachers have higher average $(\overline{\mathrm{x}}=4,17)$ than males $(\overline{\mathrm{x}}=3,90)$.

Table 10. Academic motivation levels t-test results by gender

\begin{tabular}{lllllll}
\hline Gender & $\mathbf{N}$ & $\overline{\mathbf{x}}$ & $\mathbf{S s}$ & $\mathbf{s d}$ & $\mathbf{~ t}$ & $\mathbf{p}$ \\
\hline Female & 226 & 4,55 & 0,791 & 320 & 1,14 & 0,252 \\
Male & 96 & 4,44 & 0,866 & & & \\
\hline
\end{tabular}

T-test results are presented in Table 10. When the table is examined, it is seen that there is a significant difference between the gender of prospective teachers and their academic motivation $(\mathrm{p}<0,05)$. The female prospective teachers have higher average $(\bar{x}=4,55)$ than males $(\bar{x}=4,44)$.

Table 11. Academic self-efficacy perceptions' t-test results by grade

\begin{tabular}{lllllll}
\hline Grade & $\mathbf{N}$ & $\overline{\mathbf{x}}$ & $\mathbf{S s}$ & $\mathbf{s d}$ & $\mathbf{t}$ & $\mathbf{p}$ \\
\hline 3rd grade & 173 & 4,01 & 0,489 & 320 & 3,23 & 0,001 \\
4th grade & 149 & 4,19 & 0,551 & & & \\
\hline
\end{tabular}

T-test results are presented in Table 11. When the table is examined, it is seen that there is a significant difference between the grade of prospective teachers and their academic self-efficacy $(\mathrm{p}<0,05)$. The prospective teachers in 4 th grade have higher average $(\overline{\mathrm{x}}=4,19)$ than those who are in 3 rd grade $(\overline{\mathrm{x}}=4,01)$.

Table 12. Academic motivation levels' t-test results by grade

\begin{tabular}{lllllll}
\hline Grade & $\mathbf{N}$ & $\overline{\mathbf{x}}$ & Ss & sd & $\mathbf{~ t}$ & $\mathbf{p}$ \\
\hline 3rd grade & 173 & 4,50 & 0,789 & 320 & 0,372 & 0,710 \\
4th grade & 149 & 4,54 & 0,846 & & & \\
\hline
\end{tabular}

When the table 12 is examined, it is seen that there is no significant difference between the grade of prospective teachers and their academic self-efficacy $(\mathrm{p}<0,05)$. 
Table 13. Academic self-efficacy perceptions' the variance analysis results by department

\begin{tabular}{lllllllc}
\hline & Department & $\mathbf{N}$ & $\overline{\mathbf{x}}$ & $\mathbf{S s}$ & $\mathbf{s d}$ & $\mathbf{F}$ & $\mathbf{p}$ \\
\cline { 2 - 7 } & preschool education & 36 & 4,41 & 0,453 & 321 & 6,875 & 0,000 \\
& primary school teaching & 39 & 4,20 & 0,475 & & & \\
computer and instructional & 38 & 3,85 & 0,630 & & & \\
Academic & technologies & & & & & & \\
Self-efficacy & English language teaching & 29 & 4,00 & 0,359 & & \\
& special education & 28 & 3,90 & 0,590 & & \\
& social sciences teaching & 30 & 3,94 & 0,567 & & \\
& elementary mathematics education & 30 & 3,83 & 0,402 & & \\
& psychological counseling and & 26 & 4,15 & 0,468 & & \\
& guidance & & & & & & \\
& science teaching & 35 & 4,44 & 0,401 & & & \\
& Turkish teaching & 31 & 4,13 & 0,435 & & \\
\hline
\end{tabular}

The results of the variance analysis show that there is a significant difference between the departments of prospective teachers and their academic self-efficacy $(\mathrm{p}<0,05)$.According to the Tukey multiple comparison test which is used to determine significant differences between groups, significant differences were found between preschool education-computer and instructional technologies, preschool education-English language teaching, preschool education-special education, preschool education-social sciences teaching, preschool education-elementary mathematics education, science teaching-computer and instructional technologies, science teaching-English language teaching, science teaching-special education, science teaching-social sciences teaching and science teaching-elementary mathematics education. According to this, the arithmetical average of science teaching department $(\overline{\mathrm{x}}=4,44)$ and preschool education department $(\overline{\mathrm{x}}=4,41)$ is at a "high" level. From this point, it could be stated that the perceptions of pre-school and science prospective teachers towards academic self-efficacy are higher than those of prospective teachers who study English language teaching, special education teaching, social sciences teaching elementary mathematics education teaching.

Table 14. Academic motivation levels' the variance analysis results by department

\begin{tabular}{lllllllc}
\hline & Department & $\mathbf{N}$ & $\overline{\mathbf{x}}$ & $\mathbf{S s}$ & $\mathbf{s d}$ & $\mathbf{F}$ & $\mathbf{p}$ \\
\cline { 2 - 7 } & preschool education & 36 & 4,53 & 0,808 & 321 & 2,233 & 0,020 \\
& primary school teaching & 39 & 4,51 & 0,764 & & & \\
Academic Motivation & computer and instructional technologies & 38 & 4,57 & 0,920 & & & \\
& English language teaching & 29 & 4,14 & 0,934 & & \\
& special education & 28 & 4,56 & 0,815 & & \\
& social sciences teaching & 30 & 4,55 & 0,831 & & \\
& elementary mathematics education & 30 & 4,24 & 0,741 & & \\
& psychological counseling and guidance & 26 & 4,88 & 0.480 & & \\
& science teaching & 35 & 4,79 & 0,793 & & & \\
& Turkish teaching & 31 & 4,40 & 0,793 & & & \\
\hline
\end{tabular}

The results of the variance analysis show that there is a significant difference between the departments of prospective teachers and their academic motivation $(\mathrm{p}<0,05)$. According to the Tukey multiple comparison test which is used to determine significant differences between groups, significant differences were found betweenEnglish language teaching-psychological counseling and guidance and English language teaching-science teaching. According to this, the arithmetical average of psychological counseling and guidance department $(\overline{\mathrm{x}}=4,88)$ and science teaching department $(\overline{\mathrm{x}}=4,79)$ is at a "high" level. From this point, it could be stated that the perceptions of psychological counseling and guidance and science prospective teachers towards academic motivation are higher than those of prospective teachers who study English language teaching $(\bar{x}=4,14)$. 
Table 15. Correlations between academic self-efficacy perceptions and academic motivation levels: correlation of Pearson

\begin{tabular}{ll}
\hline & Academic Self-efficacy \\
\hline Academic Motivation &, $301^{* *}$ \\
External Motivation Regulation-DMD &, $582^{* *}$ \\
External Motivation Recognition-DMT &, $663^{* *}$ \\
External Motivation Self-Proof-DMKI &, $813^{* *}$ \\
Internal Motivation Knowing- IMBI &, $739^{* *}$ \\
Internal Motivation Achievement-IMBA &, $835^{* *}$ \\
Internal Motivation Movement-IMH &, $748^{* *}$ \\
Non-Motivation-MS &, $109^{*}$
\end{tabular}

As seen from Table 15, there is a positive correlation between the academic self-efficacy perceptions and the academic motivation levels of the research group. $(\mathrm{r}=0.301, \mathrm{p}<.01)$. In this regard, it could be said that academic self-efficacy perceptions of the prospective teachers increase as long as the academic motivation levels of them increase.

In a similar manner, there is a highly positive and meaningful relationship between academic self-efficacy and external motivation recognition sub-dimension $(\mathrm{r}=0.582, \mathrm{p}<.01)$, external motivation recognition sub-dimension $(\mathrm{r}=0.663, \mathrm{p}<.01)$, external motivation self-proof sub-dimension $(\mathrm{r}=0.813, \mathrm{p}<.01)$, internal motivation knowing sub-dimension $(\mathrm{r}=0.739$, $\mathrm{p}<.01)$, internal motivation achievement sub-dimension ( $\mathrm{r}=0.835, \mathrm{p}<.01)$, internal motivation movement sub-dimension $(\mathrm{r}=0.748, \mathrm{p}<.01)$ while there is a positive and meaningful relationship at weak level between academic self-efficacy and non-motivation sub-dimension $(\mathrm{r}=0.109, \mathrm{p}<, 01)$.

\section{Results, Conclusions and Recommendations}

The results of analyses indicated that academic self-efficacy perception levels of the prospective teachers were at desired level. However, their academic motivation levels were at middle level. In terms of gender variables, the self-efficacy perceptions of prospective teachers differ significantly in favor of female candidates. Çakır, Erkuş and Kılıç (2004) and Şeker, Deniz and Görgen (2005)'s findings show parallelism with the research findings. However, it differs from the findings of Savran and Çakıroğlu (2001), Zengin (2003), Erişen and Çeliköz (2003), Çakır (2005), Çakır, Kan and Sünbül (2006) and Akbaş and Çelikkaleli (2006). This finding suggests that female prospective teachers consider themselves more proficient than male prospective teachers in terms of the self-efficacy perceptions. The fact that the gender variable has a moderate effect indicates that this variable has a significant effect on the self-efficacy perceptions. The different research results suggest that the prospective teachers have an important influence on the self-efficacy perceptions of, but that research in this field should be carried out.

In the study, it was observed that academic motivation did not differ significantly in terms of gender of prospective teachers. In the same way, it was concluded that the level of academic motivation of the students did not differ significantly in terms of gender in the studies conducted by Şahin and Çakar (2011) on fourth grade undergraduate students and by Demir and Arı (2013) on prospective teachers in the primary school teaching department. Similar results were reported in studies on graduate students (Saracaloğlu, 2008) and prospective teachers (Saracaloğlu ve Kumral, 2007; Saracaloğlu et al.., 2008a, 2008b). In the study of Eymur and Geban (2011), it was found that there was a statistically significant difference in "internal motivation/ stimulation" dimension only and the academic motivation scores of women were higher than the academic motivation scores of men. In many studies conducted on different branch prospective teachers, it is observed that the level of academic motivation does not change according to gender.

According to the results of the research, academic motivations of participants do not differ significantly from class variables. In a study of the impact of the class variable on academic motivation, it was evaluated that negative motivation points fall towards the fourth class, but also it was determined that the academic motivation scores of the 1 . grade students were higher than the academic motivation scores of the other level students (Eymur ve Geban, 2011). Gençay and Gençay (2007)'s study determines the motivation of the first classes (external motivation) is high, whereas Tekin et al. (2009)'s study it was determined that the motivation values of the fourth-class students were higher than the others.

As a result of the research, it was determined that the self-efficacy perceptions of prospective teachers differ in favor of 
prospective teachers who were educated in the fourth grade according to the class variable. Küçük Kılıç and Öncü (2013) found that prospective teachers in third grade have higher academic self-efficacy scores, whereas Oğuz (2012) found that prospective teachers in fourth grade have higher academic self-efficacy scores.

In the present study, it was determined that the views of prospective teachers regarding motivation levels differ in terms of Department variables. At this point, it was determined that the prospective teachers who are studying in psychological counseling and guidance and science departments are higher than the prospective teachers who are studying in English department. In contrast, Şahin and Çakar (2011) examined the effects of learning strategies and academic motivation levels on academic achievement of faculty of education students in a different study related to this result. According to the results of the study, the average academic motivation levels of students who study in Science and Physical Education Teaching are higher than the average academic motivation levels of students who continue their education in Music Education Teaching. Studies can be carried out to provide an in-depth examination of the source of differentiation related to motivation levels of prospective teachers.

According to the department variable, it was determined that teachers' perceptions of self-efficacy differ significantly. Prospective teachers who are studying in preschool education and science education programs perceive themselves more proficient than prospective teachers who are studying in English teaching, special education teaching, social studies teaching and mathematics teaching departments. In the study conducted by Çakır, Kan and Sünbül (2006), it was determined that the perceptions of self-efficacy of the students participating in social fields education program were higher for the students participating in science and mathematics education program and in the study conducted by Gürbüztürk and Şad (2009), it was determined that the students who were educated in the Departments of Physical Education, painting, music and classroom teaching have higher self-efficacy beliefs than those who were educated in the Departments of Science, Mathematics and English teaching.

As a result of the research, the correlation coefficients between the academic motivations and academic self-efficacy of participants were found to be significant. In a study conducted by Akbay and Gizir (2010) on undergraduate students, it was determined that there was a significant and positive relationship between academic self-efficacy and academic motivation. The results were interpreted as the students who had a high motivation to succeed did not give up quickly in the face of difficulties, and similarly the students who had a high self-sufficiency belief exhibited a high performance and insistence to solve the problem.

In addition, it is thought that planning studies to maximize students' academic motivation and academic self-efficacy levels and to do research the low levels of academic self-efficacy of male participants will contribute to the literature. Also, the fact that the study group consists of students who study at a single university can be evaluated within the scope of the limitation of the study. Further studies are expected to require larger sample groups.

\section{References}

Akbaş, A., \& Çelikkaleli, Ö. (2006). Sınıf öğretmeni adaylarının fen öğretimi özyeterlik inançlarının cinsiyet, öğrenim türü ve üniversitelerine göre incelenmesi. Mersin Üniversitesi Ĕ̈itim Fakültesi Dergisi, 2(1), 98-110.

Akbay, S. E., \& Gizir, C. A. (2010). Cinsiyete göre üniversite öğrencilerinde akademik erteleme davranışı: Akademik güdülenme, akademik özyeterlik ve akademik yükleme stillerinin rolü. Mersin Üniversitesi Eğitim Fakültesi Dergisi, 6(1), 60-78

Alderman, M. K. (2004). Motivation for achievement: Possibilities for teaching and learning $\left(2^{\text {nd }}\right.$ ed.). New Jersey: Lawrence Erlbaum Associates Publishers.

Ali, Z., Tatlah, A. I., \& Saeed, M. (2011). Motivation and student's behaviour: A tertiary level study. International Journal of Psychology and Counselling, 3(2), 29-32.

Azar, A. (2010). Ortaöğretim fen bilimleri ve matematik öğretmeni adaylarının öz yeterlilik inançları. ZKÜ Sosyal Bilimler Dergisi, 6(12), 235-252.

Bandura, A. (1977). Social Learning Theory. Albert Bandura (Ed), New Jersey: Prentice Hall

Bandura, A. (1997). Self-Efficacy: The exercise of control. New York: Freeman.

Bıkmaz, H. F. (2004). Sınıf öğretmenlerinin fen öğretiminde öz yeterlik inancı ölçeğinin geçerlik ve güvenirlik çalışması", Milli Eğitim Dergisi, 31(161), 172-180.

Çakır, Ö. (2005). Anadolu üniversitesi açıköğretim fakültesi ingilizce öğretmenliği lisans programı ve eğitim fakülteleri ingilizce öğretmenliği lisans programı öğrencilerinin mesleğe yönelik tutumları ve mesleki yeterlik algıları. İnönü Üniversitesi Eğitim Fakültesi Dergisi, 6(9), 27-42.

Çakır, Ö., Erkuş, A., \& Kılıç, F. (2000). Mersin üniversitesi 1999-2000 yılı öğretmenlik meslek bilgisi programının 
(ÖMBP) çeşitli değişkenler açısından değerlendirilmesi. Mersin Üniversitesi Araştırma Fonu Saymanlığı EF (ÖÇ) 2000-1 Nolu Araştırma Projesi.

Çakır, Ö., Kan, A., \& Sünbül, Ö. (2006). Öğretmenlik meslek bilgisi ve tezsiz yüksek lisans programlarının tutum ve özyeterlik açısından değerlendirilmesi. Mersin Üniversitesi Eğitim Fakültesi Dergisi, 2(1), 36-47.

Coetzee, L. R. (2011). The Relationship Between Students' Academic SelfConcept, Motivation and Academic Achievement at the University of the Free State. Master of Education-with Specialisation in Adult Education, University of South Africa.

Çömlekçi, N. (2001). Bilimsel araştırma yöntemi ve istatistiksel anlamlılık sınamaları. Ankara: Bilim Teknik Yayınevi.

Deci, E. L., \& Ryan, R. M. (2000/1). Intrinsic and extrinsic motivations: Classic definitions and new directions. Contemporary Educational Psychology, 25, 54-67.

Demir, G. M. (2015). Üniversite Öğrencilerinin Akademik Motivasyon Profillerinin Psikolojik İhtiyaç Doyumu, Akademik Erteleme Ve Yaşam Doyumu İle İlişkisi. Anadolu Üniversitesi EğitimBilimleri Enstitüsü, Yayımlanmış Doktora Tezi, Eskişehir.

Demir, M. K., \& Arı, E. (2013). Öğretmen adaylarının akademik güdülenme düzeylerinin çeşitli değişkenler açısından incelenmesi. Eğitimde Kuram ve Uygulama, 9(3), 265-279.

Demirel, Ö. (2012). Ĕ̆itim Sözlüğ̈̈ (5. b.). Ankara: Pegem Akademi.

Erişen, Y., \& Çeliköz, N. (2003). Öğretmen adaylarının genel öğretmenlik davranışları açısından kendilerine yönelik yeterlilik algıları. Türk Eğitim Bilimleri Dergisi, 1(4), 427-439.

Eymur, G., \& Geban, Ö. (2011). Kimya öğretmeni adaylarının motivasyon ve akademik başarıları arasındaki ilişkinin incelenmesi. Eğitim ve Bilim, 36(161), 246-255.

Fortier, M. S., Vallerand, R. J., \& Guay, F. (1995). Academic motivation and school performance: Toward a structural model. Contemporary Educational Psychology, 20, 257-274.

Gençay, Ö. A., \& Gençay, S. (2007). Beden eğitimi ve spor yüksekokulu öğrencilerinin öğretmenlik mesleğine ilişkin motivasyon düzeylerinin bazı değişkenler açısından incelenmesi. Selçuk Üniversitesi Sosyal Bilimler Enstitüsü Dergisi, 17(241), 241-253.

Gökçe, B. (1988). Toplumsal bilimlerde araştırma. Ankara: Savaş Yayınları. Ankara: Savaş Yayınları.

Gömleksiz, M. N., \& Serhatlıoğlu, B. (2014). Öğretmen adaylarının akademik motivasyon düzeylerine ilişkin görüşleri. Türkiye Sosyal Araştırmalar Dergisi, 173(173), 99-128.

Guay, F., Mageau, G. A., \& Vallerand, R. J. (2003). On the hierarchical structure of self-determined motivation: A test of top-down, bottom-up, reciprocal, and horizontal effects. Personality and socialpsychology bulletin, 29(8), 992-1004.

Gürbüztürk, O., \& Şad, S. N. (2009). Student teachers' beliefs about teaching and their sense of self-efficacy: A descriptive and comparative analysis. İnönü Üniversitesi Eğitim Fakültesi Dergisi, 10(3), 201-226.

Hardre', P. L., Chen, C. H., Huang, S. H., Chiang, C. T., Jen, F. L., \& Warden, L. (2006). Factors affecting high school students' academic motivation in Taiwan. Asia Pasific Journal of Education, 26(2), 189-207.

Henning, M. (2007). Students' Motivation to Learn, Academic Achievement, and Academic Advising. Unpublished doctoral dissertation, AUT University, New Zealand.

Karagüven, M. (2012). Akademik motivasyon ölçeğinin Türkçeye adaptasyonu. Kuram ve Uygulamada Eğitim Bilimleri, 12(4), 1-22.

Karasar, N. (2012). Bilimsel Araştırma Yöntemi (25. b.). Ankara: Nobel Yayın Dağıtım.

Küçük, K. S., \& Öncü, E. (2013). 6.Ulusal Spor Bilimleri Öğrenci Kongresi: Beden eğitimi ve spor yüksekokulu öğrencilerinin bilişötesi öğrenme stratejileri ve akademik öz-yeterlikleri. Kayseri: Erciyes Üniversitesi.

Nachmias, C., \& Nachmias, D. (1996). Research Methods in the Social Sciences. (5. b.). New York: St. Martin's Press.

Oğuz, A. (2012). Academic self-efficacy beliefs of prospective primary school teachers. Anadolu Journal of Educational Sciences International, 2(2), 15-28.

Rigby, C. S., Deci, E. L., Patrick, B. C., \& Ryan, R. M. (1992). Beyond the intrinsic-extrinsic dichotomy: Self-determination in motivation and learning. Motivation and Emotion, 16(3), 165-185.

Şahin, H., \& Çakar, E. (2011). Eğitim fakültesi öğrencilerinin öğrenme stratejileri ve akademik güdülenme düzeylerinin 
akademik başarılarına etkisi. Türk Eğitim Bilimleri Dergisi, 9(3), 519-540.

Saracaloğlu, A. S. (2008). Lisansüstü öğrencilerin akademik güdülenme düzeyleri, araştırma kaygıları ve tutumları ile araştırma yeterlikleri arasındaki ilişki. Yüzüncü Yll Üniversitesi Eğitim Fakültesi Dergisi, 5(2), 179-208.

Saracaloğlu, A. S., \& Kumral, O. (2007). VI. Ulusal Sınıf Öğretmenliği Eğitimi Sempozyumu: Sınıf öğretmenliği son sınıf öğrencilerinin öğretmenlik mesleğine yönelik yeterlik algıları, kaygıları ve akademik güdülenme düzeylerinin çeşitli değişkenler açısından incelenmesi. Eskişehir: Anadolu Üniversitesi.

Saracaloğlu, A. S., Karasakaloğlu, N., \& Yenice, N. (2008a). VII. Ulusal Sınıf Öğretmenliği Eğitimi Sempozyumu: Sınıf öğretmeni adaylarının akademik güdülenme düzeyleri, fen ve sosyal bilimlere ilişkin görüşleri ile akademik başarıları arasındaki ilişsi. Çanakkale: Onsekiz Mart Üniversitesi.

Saracaloğlu, A. S., Kumral, O., \& Kanmaz, A. (2008b). Uluslararası Sosyal Bilimler Eğitimi Sempozyumu: Ortaöğretim sosyal alanlar öğretmenliği tezsiz yüksek lisans öğrencilerinin öğretmenlik mesleğine yönelik yeterlikleri, kaygıları ve akademik güdülenme düzeyleri. Çanakkale.

Savran, A., \& Çakıroğlu, J. (2001). Preservice biology teachers' perceived efficacy beliefs in teaching biology. Hacettepe Üniversitesi Ĕ̈itim Fakültesi Dergisi, 21, 105-112.

Scherbaum, C. A., Cohen-Charash, Y., \& Kern, M. J. (2006). Measuring General Self Efficacy: A Comparison Of Three Measures Using Item Response Theory. Educational and Psychological Measurement, 66(6), 1047-1063.

Şeker, H., Deniz, S., \& Görgen, İ. (2005). Tezsiz yüksek lisans öğretmen adaylarının öğretmenlik yeterlikleri üzerine değerlendirmeleri. Kuram ve Uygulamada Eğitim Yönetimi Dergisi, 42, 237-253.

Slavin, R. E. (2006). Educational Psychology Theory and Practise (8th ed.). Boston: Pearson.

Sternberg, R. J., \& Williams, W. M. (2009). Educational Psychology (2nd ed.). New Jersey: Pearson.

Tekin, M., Taşğın, Ö., Yıldız, M., \& Lök, S. (2009). 6. Ulusal Beden Eğitimi ve Spor Öğretmenliği Sempozyumu: Beden eğitimi ve spor yüksekokulunda öğrenim gören öğretmen adaylarının öğretmenlik mesleğine ilişkin motivasyon düzeyleri. Burdur: Mehmet Akif Üniversitesi.

Vallerand, R. J., Pelletier, L. G., Blais, M. R., Brière, N. M., Senecal, C., \& Vallières, É. F. (1993). On the assessment of intrinsic, extrinsic, and amotivation in education: Evidence on the concurrent and construct validity of the Academic Motivation Scale. Educational and psychological measurement, 53(1), 159-172.

Wentzel, K. R., \& Wigfield, A. (1998). Academic and social motivational influences on students' academic performance. Educational Psychology Review, 10(2), 155-175.

Yıldırım, F., \& İlhan, İ. Ö. (2010). Genel Özyeterlilik Ölçeği Türkçe Formunun Geçerlik ve Güvenilirlik Çalışması. Türk Psikiyatri Dergisi, 21(4), 301-308.

Zengin, U. (2003). İlköğretim Öğretmenlerinin Özyeterlik Algıları ve Sınıf İçi İletişim Örüntüleri. D.E.Ü. Eğitim Bilimleri Enstitüsü Yayımlanmamış Yüksek Lisans Tezi, İzmir.

\section{Copyrights}

Copyright for this article is retained by the author(s), with first publication rights granted to the journal.

This is an open-access article distributed under the terms and conditions of the Creative Commons Attribution license which permits unrestricted use, distribution, and reproduction in any medium, provided the original work is properly cited. 